\title{
Evaluation of Tensile Bond Strength of Metallic Prefabricated Posts Cemented with Different Luting Agents
}

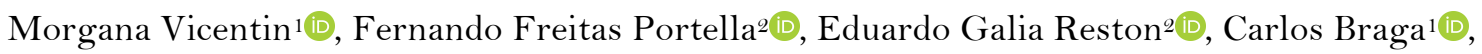

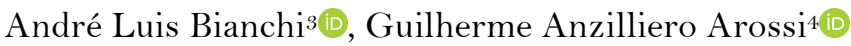

\begin{abstract}
${ }^{1}$ Dental School, Lutheran University of Brazil, Canoas, RS, Brazil.
${ }^{2}$ Post-Graduation Program in Dentistry, Lutheran University of Brazil, Canoas, RS, Brazil.

${ }^{3}$ Electrical Engineering School, Lutheran University of Brazil, Canoas, RS, Brazil.

${ }^{4}$ Post-Graduation Program in Health Promotion, Lutheran University of Brazil, Canoas, RS, Brazil.
\end{abstract}

Author to whom correspondence should be addressed: Guilherme Anzilliero Arossi, Dental School and Post-Graduation Program in Health Promotion, Universidade Luterana do Brasil, Avenida Farroupilha 8001, Canoas, RS, Brazil. 92425-900. Phone: +55 51997188336. E-mail: guilhermeclinica@gmail.com.

Academic Editors: Alessandro Leite Cavalcanti and Wilton Wilney Nascimento Padilha

Received: 07 June 2019 / Accepted: 15 April 2020 / Published: 25 May 2020

\begin{abstract}
How to cite this article: Vicentin M, Portella FF, Reston EG, Braga C, Bianchi AL, Arossi GA. Evaluation of tensile bond strength of metallic prefabricated posts cemented with different luting agents. Pesqui Bras Odontopediatria Clín Integr. 2020; 20:e4009. https://doi.org/10.1590/pboci.2020.089
\end{abstract}

\begin{abstract}
Objective: To assess the tensile bond strength of prefabricated metal posts cemented with different luting agents. Material and Methods: Fifty single-rooted endodontically treated human teeth had their crowns cut, mounted into acrylic-resin blocks and then an $8 \mathrm{~mm}$ depth post space were prepared. Prefabricated cylindrical metal posts were cemented using different luting agents: a zinc phosphate cement (SS White), a conventional glass ionomer cement (Vidrion C), two resin-modified glass ionomer cements (Vitremer and RelyX Luting 2) and a resin cement (RelyX ARC). Samples were stored in distilled water for seven days and then submitted to a tensile bond strength test until complete dislocation of the post. One-way analysis of variance and Tukey test for pairwise multiple comparisons were used to evaluate differences between luting agents. Results: Tensile bond strength was $563.88 \pm 203.41 \mathrm{~N}$ for zinc phosphate cement, 336.86 $\pm 137.64 \mathrm{~N}$ for Vidrion C, $515.24 \pm 239.48 \mathrm{~N}$ for Vitremer, 828.47 $\pm 433.99 \mathrm{~N}$ for RelyX Luting 2 and 1262.51 \pm 356.29 for RelyX ARC. The Relyx ARC presented the highest tensile bond strength regard the luting agent tested $(\mathrm{p}<0.05)$. Conclusion: RelyX ARC presented the higher tensile bond strength compared to the other luting agents evaluated.
\end{abstract}

Keywords: Dental Cements; Glass Ionomer Cements; Post and Core Technique; Resin Cements. 


\section{Introduction}

Restorative dentistry currently provides various routine methods for rehabilitation of endodontic treated teeth with compromised coronary structure [1]. In order to rehabilitate these treated roots and to provide coronary reconstruction, an intracanal post could be necessary to support the crown restoration [2-5]. However, these teeth are more fragile and, therefore, there is a greater risk of root fractures due to dental function [2-5].

Posts are designed to retain the build-up material that substitutes the lost coronal dental structure $[4,5]$. Basic concepts, such as the proper length and shape of a post suitable for the root, continue to be the best clinical parameters employed in post and core technique, independent of the post type or material of which they are made $[5,6]$. The restorative approach has been unclear with respect to the type of post to be used, as well as the longevity acquired by each type of restorative material and technique used [5]. There are clinical variables that confuse the post and core technique choice, such as luting agent composition, thickness of the luting agent in post-root interface, post shape and composition, post space preparation, dentin preparation, extent of dental structure loss and occlusal stress [5]. However, the metallic post still be an option when aesthetic was not required. When used, they could be cemented using zinc phosphate cement [7], being a cheap treatment option.

Concerning to cement choice, adhesion is required among restorative components, intracanal posts, luting agents, and remaining tooth, in order to develop a homogeneous unit structure from mechanical and functional point-of-views [8]. Luting agent choice should be made by a clinical set including post type, convenience of tooth preparation, and case planning, with the purpose of attending to its biological and functional necessities. The prefabricated metal post has the disadvantage to not fit perfectly to the dentin wall of post space, thus enhancing the film thickness of luting agent. In these situations, the luting agent is more challenged and optimum chemo-mechanical properties are desired in order to avoid failure of the post-luting agent-dentin unit and jeopardize treatment longevity.

Currently, different types of luting agents are available, and it is necessary to improve the understanding of these agents to choose them based on scientific evidence [9,10]. Conventional glass ionomer cements have the benefits of fluoride release and chemical bond to tooth structure, while the drawbacks are susceptibility to dehydration, low tensile strength, and very low fracture resistance [11]. Resin-modified glassionomer cements contain monomers that enhance its physical and mechanical properties, preserving the anticariogenic properties and chemical bond to dentin [11]. Zinc phosphate cements have great strength, low solubility, and they have been used successfully in dentistry for a long time, mainly associated with metal cast post and core [12]. Resin cements show lower solubility and adequate marginal sealing. The disadvantage of resin cements its high sensible application technique [12,13].

Thus, the aim of this study was to assess the tensile bond strength of prefabricated metal posts cemented with different luting agents.

\section{Material and Methods}

Ethical Considerations

This study was conducted after the project's review and approval by the Ethics Committee of Lutheran University of Brazil, Code 572.862.

Sample Preparation 
The teeth used were collected at a tooth bank (Lutheran University of Brazil, Torres, Brazil). The same operator, properly trained, carried out all sample preparation and luting procedures.

Fifty single-rooted endodontically treated human teeth were used. The average root length was $5 \mathrm{~mm}$ in the mesiodistal dimension and $7 \mathrm{~mm}$ in the bucolingual dimension, measured with a digital caliper (Coolant Proof, Mitutoyo Sul Americana, Suzano, SP, Brazil), which allowed the standardization of the sample. The collected teeth were previously used on endodontic preclinical activities of undergraduate students. Cleaning, shaping and root canal filling procedures were realized by handfiles, using $1 \%$ sodium hypochlorite as irrigant, followed by an EDTA final rinse. Gutta-percha points and a zinc oxide eugenol-based sealer was used to root canal filling by lateral condensation. Teeth had their crowns cut by a diamond bur. Roots length was adjusted to $13 \mathrm{~mm}$ and then adapted into acrylic-resin blocks for an appropriated handling. Post spaces (8 $\mathrm{mm}$ depth) were prepared by a Largo drill No. 3 mounted on a slow-speed handpiece. Endodontic obturation were maintained at apical third. Prefabricated cylindrical metal posts (Reforpost No. 3, Angelus Indústria de Produtos Odontológicos SA, Londrina, PR, Brazil) with $11.5 \mathrm{~mm}$ total length and $1.45 \mathrm{~mm}$ diameter were used. Root canals were cleaned by a rinse of $95 \%$ alcohol and dried by paper points before luting. The posts were inserted $8 \mathrm{~mm}$ deep into the root, leaving $3.5 \mathrm{~mm}$ remaining metal core in the coronary portion.

\section{Luting Procedures}

The roots were randomized in five groups $(n=10)$ and post were cemented with the followed luting agents: a zinc phosphate cement (Zinc Cement, S.S. White Duflex, Rio de Janeiro, RJ, Brazil), a conventional glass ionomer cement (Vidrion C, S.S. White Duflex, Rio de Janeiro, RJ, Brazil), two resin-modified glass ionomer cements (Vitremer and RelyX Luting 2, 3M ESPE, St. Paul, MN, USA), and a resin cement (RelyX ARC, 3M ESPE, St. Paul, MN, USA). Luting procedures were described at Table 1. The excess of luting agent was removed immediately after bond procedures, and the material was given time to cure. All samples were stored in distilled water at $37^{\circ} \mathrm{C}$ for 7 days before tensile test.

Table 1. Materials and luting procedures.

\begin{tabular}{|c|c|c|}
\hline Material & $\begin{array}{l}\text { Manufacturer and } \\
\text { Batch Number }\end{array}$ & Procedures \\
\hline Zinc Phosphate & SS White & Cement were manipulated according manufacturer's instructions, by mixing \\
\hline Cement & $0070812 / 05800812$ & $\begin{array}{l}\text { vigorously the powder and liquid using the entire area of a glass plate. The } \\
\text { mixture was inserted on the post space with the post. The post was kept under } \\
\text { pressure for } 4 \text { minutes. }\end{array}$ \\
\hline Vidrion $\mathrm{C}$ & $\begin{array}{l}\text { SS White } \\
0231013\end{array}$ & $\begin{array}{l}\text { Cement were manipulated according manufacturer's instructions. The mixture } \\
\text { was inserted on the post space with the post and it was allowed to set for } 8 \\
\text { minutes. }\end{array}$ \\
\hline Vitremer & $\begin{array}{l}\text { 3M ESPE } \\
\text { N447387/N351176 }\end{array}$ & $\begin{array}{l}\text { One measure of powder was mixed to two drops of liquid. The mixture was } \\
\text { inserted on the post space with the post and light-cured for } 40 \text { seconds } \\
\text { (Optilight LD Max, Gnatus Produtos Médicos e Odontológicos Ltda, Barretos, } \\
\text { SP, Brazil). }\end{array}$ \\
\hline RelyX Luting 2 & $\begin{array}{l}3 \mathrm{M} \text { ESPE } \\
\mathrm{N} 405443\end{array}$ & $\begin{array}{l}\text { One dose of cement was prepared by mixing the two pastes and inserted in the } \\
\text { post space with the post. It was then light-cured for } 30 \text { seconds (Optilight LD } \\
\text { Max, Gnatus Produtos Médicos e Odontológicos Ltda, Barretos, SP, Brazil). }\end{array}$ \\
\hline RelyX ARC & $\begin{array}{l}3 \mathrm{M} \text { ESPE } \\
\mathrm{N} 418919\end{array}$ & $\begin{array}{l}\text { The post space was conditioned by } 37 \% \text { phosphoric acid for } 15 \text { seconds, rinsed } \\
\text { and dried by paper points. Single bond ( } 3 \mathrm{M} \text { ESPE, St. Paul, MN, USA) adhesive } \\
\text { was applied to dentin, excess was removed by absorbent paper points and light- } \\
\text { cured (Optilight LD Max, Gnatus Produtos Médicos e Odontológicos Ltda, } \\
\text { Barretos, SP, Brazil) for } 20 \text { seconds. A dose of cement was then mixed, inserted } \\
\text { with the post in the canal and light-cured (Optilight LD Max, Gnatus Produtos } \\
\text { Médicos e Odontológicos Ltda, Barretos, SP, Brazil) for } 30 \text { seconds with } \\
800 \mathrm{~mW} / \mathrm{cm}^{2} \text { light power. }\end{array}$ \\
\hline
\end{tabular}


Tensile Bond Strength Test

After preparation and luting procedures, samples were submitted to a tensile strength by a HBM-S4O $50 \mathrm{~kg}$ load cell at a speed of $0.5 \mathrm{~mm} / \mathrm{min}$. (8500 Plus Dynamic Testing System; Instron Corp, High Wycombe, UK). Samples were placed in a metal clamp that performed the traction at the coronal portion of post, while a second part was fixed to acrylic-resin block. Each sample was coded according to its group and the operator was blinded to experimental group. The load at the total post dislocation from the root canal was considered for measurements. At this point the tensile bond strength was recorded, in Newtons, for each sample.

\section{Statistical Analysis}

Normality was assessed using Kolmogorov-Smirnov test and Shapiro-Wilk test. Homogeneity of variances was assessed by Levene's test. Tensile bond strength data were statistically analyzed by one-way analysis of variance (ANOVA), followed by Tukey test for pairwise multiple comparisons. Analysis was performed at $5 \%$ of significance, considering statistical differences among data when $\mathrm{p} \leq 0.05$.

\section{Results}

The mean and standard deviation values of tensile bond strength $(\mathrm{N})$ for each luting agent was presented on Figure 1. Zinc phosphate cement, Vidrion C, Vitremer, RelyX Luting 2 and RelyX ARC presented $563.88 \pm 203.41 \mathrm{~N}, 336.86 \pm 137.64 \mathrm{~N}, 515.24 \pm 239.48 \mathrm{~N}, 828.47 \pm 433.99 \mathrm{~N}$ and $1262.51 \pm 356.29$ $\mathrm{N}$, respectively. There is a statistical difference between tensile strength promoted by luting agents $(\mathrm{p}<0.05)$. The Relyx ARC presents the highest tensile bond strength regarding the luting agent tested.

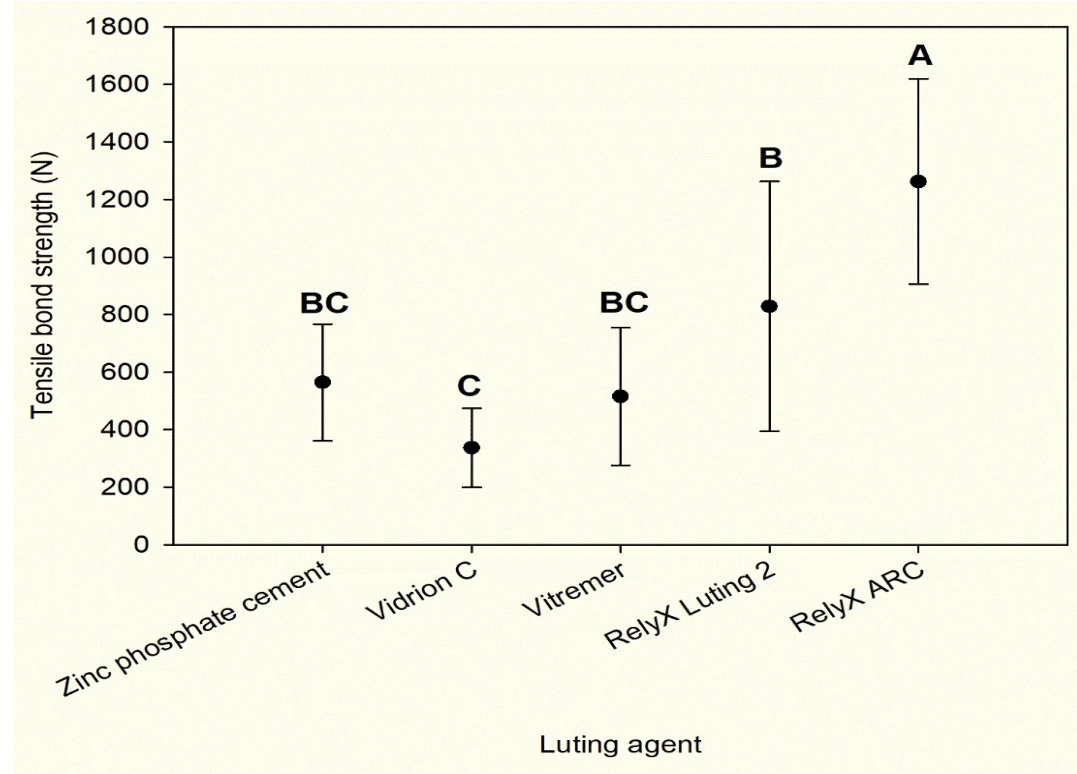

Figure 1. Tensile bond strength according luting agents (Newtons). The dot indicates the mean value and the bar indicates the standard deviation. Distinct letters indicate statistical difference $(p<0.05)$.

\section{Discussion}

In endodontically treated teeth, an intracanal retainer is used to improve dental restorative conditions. Prefabricated posts are being frequently used, in regard of metal cast post and core, and different luting agents are available for this post and core techniques. Evidence-based data should be taken in account for luting agent's selection. This study was designed to use a standard prefabricated metal post in order to isolate the 
'cement' variable. Tensile bond strength promoted by luting agents was the main outcome of this experiment. The dual resinous cement, Relyx ARC presented the highest retention regard the luting agents tested, in accordance to previous study [14]. Tensile bond strength of Zinc phosphate cement did not present statistical difference in comparison with glass-ionomer based luting agents, despite its lack of chemical adhesion to dentin. High retention of Relyx ARC could be addressed to its higher mechanical properties [15], in comparison to other luting agents, as well the micromechanical retention promoted by adhesive system [16]. Luting of prefabricated post generate a non-favorable post-luting agent-dentin unit, due to the post was not perfectly adapted to root canal walls, requiring a thicker cement film.

A direct comparison between the glass-ionomer based luting agents shows that Vidrion C, a powder/liquid material, has lower tensile bond strength than Vitremer and RelyX Luting 2, both resin modified glass ionomer based. The incorporation of resin monomers in the resin modified materials enhances its mechanical properties, increasing its retention [15]. Notwithstanding, the Vitremer, originally designed to restorations, did not overcame the tensile bond strength of RelyX Luting 2, that is a luting agent properly.

Despite the higher sensible technique application of RelyX ARC [12], its better mechanical properties overcame the higher film thickness present when metal post was used, explaining the findings of this study. Relyx ARC and Relyx Luting 2 did not present significant difference on retention on previous study [17]. However, RelyX Luting 2 had a homogeneous strength along the cementation depth compared to RelyX ARC, whose bond strength decrease in deeper areas of the cementation [17].

Bond strength evaluation of different luting agents for post cementation concludes that, using ceramic posts, resinous cement Variolink II showed significant failure compared with conventional glass ionomer cement Fuji I [18]. Our results disagreed with this data as presenting greater tensile strength for resinous cements compared to glass ionomer cement. However, these ionomer cements are able to be clinically indicated when there is some difficulty with resinous cement technique, such as moisture control and deep adhesive/cement photoactivation.

In this study, the depth of the post into the canal was standardized in $8 \mathrm{~mm}$, leaving a $5 \mathrm{~mm}$ apical obturation. The depth of the post varies in laboratory studies, it was reported with a standardized depth of 10 $\mathrm{mm}[17], 9 \mathrm{~mm}[19]$ and $8 \mathrm{~mm}[20]$, as in the present study. A minimum depth of $7 \mathrm{~mm}$ [21] was considered necessary to provide post-adequate retention. At the depth used none of the samples shows radicular curvature, and the standardization of the post space preparation guaranteed the same anatomy for all samples.

All roots used in this study has the canal treated and keep storage in distillate water for at least 30 days before used, to ensure the complete setting of root canal sealer. In the same way, the retention test was performed 7 days after cementation. All samples were obturated with zinc oxide-eugenol based root canal sealer. Nevertheless, the use of a zinc oxide-eugenol based sealer was used, which could jeopardize the adhesion of resin cements [22], in the present study the resin cement RelyX ARC presents the higher tensile strength.

A drawback of this study was the absence of a failure mode analysis. It was not recorded where the failure occurs. Besides that, none of the luting agent tested present chemical adhesion to the metal post, so it's expected that differences founded should be explained by the resistance to dislodgement between cements and dentin of canal walls.

\section{Conclusion}

RelyX ARC, a resinous cement, presented the higher tensile bond strength compared to the glass ionomer-based luting agents evaluated. 


\section{Authors' Contributions}

\begin{tabular}{|c|c|c|}
\hline MV & (iD) $0000-0003-0074-3771$ & $\begin{array}{l}\text { Conceptualization, Methodology, Formal Analysis, Investigation and Writing - } \\
\text { Original Draft Preparation. }\end{array}$ \\
\hline FFP & (iD) $0000-0003-3232-001 \mathrm{X}$ & Formal Analysis, Data Curation and Writing - Review and Editing. \\
\hline EGR & (iD) $0000-0003-0698-9465$ & Writing - Review and Editing, Visualization and Supervision. \\
\hline $\mathrm{CB}$ & (iD) $0000-0002-3109-9619$ & Writing - Original Draft Preparation. \\
\hline ALB & (iD) $0000-0001-9939-4588$ & Methodology, Investigation and Data Curation. \\
\hline GAA & (D) $0000-0001-9580-6282$ & $\begin{array}{l}\text { Conceptualization, Methodology, Formal Analysis, Investigation, Data Curation, } \\
\text { Writing - Original Draft Preparation and Supervision. }\end{array}$ \\
\hline
\end{tabular}

\section{Financial Support}

Coordenação de Aperfeiçoamento de Pessoal de Nível Superior - Brasil (CAPES).

\section{Conflict of Interest}

The authors declare no conflicts of interest.

\section{Ackowledgement}

This study was conducted as an activity of the final work to achieve the DDS degree (MV). The author (FFP) gratefully acknowledges CAPES for the scholarship as postdoctoral researcher.

\section{References}

[1] Ratnakar P, Bhosgi R, Kiran Kumar Metta, Kanika Aggarwal, S Vinuta, Navneet Singh. Survey on restoration of endodontically treated anterior teeth: a questionnaire based study. J Int Oral Health 2014; 6(6):41-5.

[2] Pereira JR, Martins LCN, Paula VG, Ghizoni JS, May NB, Pamato S, et al. Evaluation of tensile strength of fiberglass posts cemented with different glass ionomer cements through pull-out-test. RFO UPF 2012; 17(2):167-70.

[3] Ralid DCB, Ishikiriama A, Miranzi MAS, Ishikiriama SK. Provisory aesthetic and funcional whitewashing of treated endodontically tooth with prefabricated bolts: a case story. Rev Gaúcha Odontol 2007; 55(1):101-5.

[4] Mazaro JVQ, Assunção WG, Rocha EP, Zuim PRJ, Gennari Filho H. Factors determining of intraradicular post selection. Rev odontol UNESP 2006; 35(4):223-31.

[5] Bispo LB. Reconstruction of endodontically treated teeth: intraradicular retainers. Rev Gaúcha Odontol 2008; 56(1):81-4.

[6] Silva RVC, Veronezi MC, Dekon AFC, Silva PMB, Silva LM, Andrade AM. Comparison of tensile strength between metal $(\mathrm{Ni} / \mathrm{Cr})$ and fiberglass pins cemented with resin cements. Salusvita 2009; 28(1):41-51.

[7] Bohn PV. Andrioli DG, Leitune VCB, Collares FM, Botega DM, Meira DM, Samuel SMW, Fortes CBB. Cements Used for Fixed Prosthodontics: a survey with Porto Alegre specialists. Rev Fac Odontol Porto Alegre 2010; 50(3):59.

[8] Bonfante G, Pegoraro LF, Kaizer OB, Reis KR, Kaizer ROF. Influence of glass fiber post adaptation in the root canal on the tensile strength. RFO UPF 2008; 13(1):48-54.

[9] Monticelli F, Ferrari M, Toledano M. Cement system and surface treatment selection for fiber post luting. Med Oral Patol Oral Cir Bucal 2008; 13(3):E2 14-21

[10] Lad PP, Kamath M, Tarale K, Kusugal PB. Practical clinical considerations of luting cements: A review. J Int Oral Health 2014; 6(1):116-20.

[11] Sidhu SK, Nicholson JW. A review of glass-ionomer cements for clinical dentistry. J Funct Biomater 2016; 7(3): E16. https://doi.org/10.3390/jfb7030016

[12] Lad PP, Kamath M, Tarale K, Kusugal PB. Practical clinical considerations of luting cements: a review. J Int Oral Health 2014; 6(1):116-20.

[13] Nagase DY, Matos AB. Influence of two adhesive cementation technique in retention force of fiber post system. Rev Inst Ciênc Saúde 2007; 25(4):437-41.

[14] Frizzo EG, Coelho-de-Souza FH, Klein-Júnior CA, Braga C, Campos LM. Shear bond strength of composite resin luted in bovine teeth by different luting techniques. Stomatos 2009; 15(29):22-31.

[15] Rosenstiel SF, Land MF, Crispin BJ. Dental luting agents: a review of the current literature. J Prosthet Dent 1998; 80(3):280-301. https://doi.org/10.1016/s0022-3913(98)70128-3 
[16] Nakabayashi N, Kojima K, Masuhara E. The promotion of adhesion by the infiltration of monomers into tooth substrates. J Biomed Mater Res 1982; 16(3):265-73. https://doi.org/10.1002/jbm.820160307

[17] Pereira JR, do Valle AL, Ghizoni JA, Lorenzoni FC, Só MVR. Push-out bond strengths of different dental cements used to cement glass fiber posts. J Prosthet Dent 2013; 110(2):134-40.

https://doi.org/10.1016/So022-3913(13)60353-4

[18] Marchan S, Coldero L, Whiting R, Barclay S. In vitro evaluation of the retention of zirconia-based ceramic posts luted with glass ionomer and resin cements. Bras Dent J 2005; 16(3):213-7.

[19] Zicar, F, De Munck J, Scotti R, Naert I, Van Meerbeek B. Factors affecting the cement-post interface. Dent Mater 2012; 28(3):287-97. https://doi.org/10.1016/j.dental.2011.11.003

[20] Aleisa K, Al-Dwairi ZN, Alghabban R, Goodacre CJ. Effect of luting agents on the tensile bond strength of glass fiber posts: An in vitro study. J Prosthet Dent 2013; $110(3)$ :2 16-22. https://doi.org/10.1016/So022-3913(13)60360-1

[21] Dastgurdi ME, Khabiri M, Khademi A, Jahromi MZ, Dastnaei PH. Effect of post length and type of luting agent on the dislodging time of metallic prefabricated posts by using ultrasonic vibration. J Endod 2013; 39(11):1423-7. https://doi.org/10.1016/j.joen.2013.07.005

[22] Altmann AS, Leitune VC, Collares FM. Influence of eugenol-based sealers on push-out bond strength of fiber post luted with resin cement: systematic review and meta-analysis. J Endod 2015; 41(9):1418-23. https://doi.org/10.1016/j.joen.2015.05.014 